\title{
Adrenal hormone insufficiency impact on antioxidant metabolism in the tissues of rat
}

\author{
K. K avitha' ${ }^{1}$ M . M ohana Radhika ${ }^{1}$, E. M adhuri ${ }^{2}$, W. Rajendra ${ }^{1}$ and M . B haskar ${ }^{1 *}$ \\ ${ }^{1}$ Department of Zoology, S.V. University, Tirupati-517502 (A.P.), INDIA \\ ${ }^{2}$ Department of Zoology, Yogivemana University, Kadapa (A.P.), INDIA \\ *Corresponding author. E-mail: matchabhaskar@yahoo.com
}

\begin{abstract}
The effect of adrenelectomy was studied on the antioxidant metabolism in different tissues (Liver, heart, kidney and muscle) of rat. G-6-PDH was increased significantly in liver and heart and the same was decreased in kidney with a non significant change in muscle. SOD was significantly increased in heart and muscle. Catalase was significantly decreased in liver and muscle and was increased significantly in kidney. XOD showed significant decrease in liver and increase in heart, kidney and muscle. The present finding, in general, exhibit tissue specific alterations in free radical metabolism in conjunction with antioxidant defence mechanisms during adrenal hormone deficiency. It is also clear from the results that the mechanisms involved in selective activation / inhibition of different pathways seems to reflect multifaceted physiological adaptations as a compensatory measure during induced adrenalectomy.
\end{abstract}

Keywords: Adrenalectomy, Antioxidant metabolism, Sham operated, Tissue

\section{INTRODUCTION}

Adrenalectomy is associated with stress, resulting in marked changes in all physiological activities, including the production of free radicals. Heart faces high rate of free radical injury owing to a slow generation of antioxidant enzymes (AOE) by its cells (Asha Devi et al., 2003). When the body's normal defense system against free radicals are overwhelmed, oxidative stress increases (Schroder et al., 2001). Increased production of ROS is a feature of most, if not all, human diseases including cardiovascular diseases and cancer (Jacob and Burri, 1996). Adrenalectomized rats produce superoxide anion free radical, and their production are increased by cortisol therapy, suggesting that their formation may contribute to some of the harmful effects of corticosteroids when given in more physiologic amounts (Nelson and Ruhmann-Wennhold, 1975).

The biological systems are protected from the hazardous effects of toxic compounds by not only antioxidants but also by detoxification enzyme systems (Helmutsies, 1985).

The enzymatic system includes a wide array of antioxidant quenchers such as glucose-6-phosphate dehydrogenase (G-6-PDH), superoxide dismutase (SOD), catalase (CAT) and xanthine oxidase (XOD). The present investigation is aimed to study the alterations in activation of antioxidant metabolism in selected tissues of rat during adrenelectomy.

\section{MATERIALS AND METHODS}

Male, pathogen-free Wistar strain albino rats aged 3 months were obtained from Indian Institute of Sciences, Bangalore. They were housed and maintained in clean polypropylene cages, six in each, in a temperature controlled room $\left(27^{\circ} \mathrm{C}\right)$ with photo-period of $12 \mathrm{hrs}$ light and $12 \mathrm{hrs}$ dark cycles. The rats were fed with standard laboratory chow (Hindustan Lever Ltd., Mumbai) and water ad libitum.

Experimental design: Rats were divided into two groups, each group consists of six individuals. First group of rats were called as sham operated (SO), the adrenals were kept intact and considered as control. The second group of rats were bilaterally adrenalectomized (ADX) by the dorsal approach in a single stage operation as described by Bhaskar et al., 1989. The rats were anaesthetized before surgery using ether. Adrenalectomized rats were given $0.9 \%$ saline as drinking water and sham operated rats were given normal tap water.

The control and experimental rats were maintained for three weeks period. The three week period was chosen on the basis of preliminary data showing that three week period of adrenalectomy produced effects consistent with adrenal hormone insufficiency (Bhaskar et al., 1989). After the three weeks of experimental period, the rats were sacrificed by cervical dislocation and the tissues like liver, heart, kidney and muscle were isolated, chilled immediately. 


\section{RESULTS}

The alterations in selected antioxidant enzymes during Adx were presented in tables 1 and 2 . The activity of glucose-6-phosphate dehydrogenase showed a significant increase in the liver of adrenalectomized rat than sham operated. Similar to liver, heart tissue of adrenalectomized rat showed significant increase in G-6PDH activity compared to sham operated. In contrast to liver and heart, kidney tissue of adrenalectomized rat showed reduced activity of G-6-PDH.

The heart and muscle tissues of adrenalectomized rats showed significant increase in SOD activity over sham operated. Liver showed a significant decrease in the catalase activity of adrenalectomized rat than sham operated. Similar to liver, adrenalectomy imposed decreased activity of catalase in the muscle tissue compared to sham operated. Kidney tissue of adrenalectomized rat showed increase in catalase activity when compared to sham operated.

Liver showed a significant decrease in the XOD activity of adrenalectomized rat than sham operated. Heart, kidney and muscle tissues of adrenalectomized rat showed significant increase in XOD activity when compared to sham operated.

\section{DISCUSSION}

Adrenalectomized rat liver showed a significant increase in G-6-PDH activity in both liver and Heart. The HMP shunt, the only source for direct glucose oxidation besides TCA cycle provides energy to animal on one hand and help in detoxification process by producing NADPH on the other hand. The G-6-PDH activity was increased in sympathectomized liver of adrenalectomized rats (Parfenova and Shanygina, 1976). Adrenalectomized animals had higher G-6-PDH and Malic enzyme (ME) activities and higher liver lipid levels than the shamoperated rats (Kaul and Berdanier, 1975).

Kidney showed a significant decrease in G-6-PDH activity in adrenalectomized rats than sham operated. The decreased activity of G-6-PDH during adrenalectomy may suggest decreased conversion of glucose-6-phosphate to 6-phosphogluconolactone, leading to reduced formation of $\mathrm{NADPH}_{2}$ through HMP shunt. The declined G-6-PDH activity observed in the present study subsequently brings about a fall in GSH levels.

Xanthine oxidase is the source of superoxide anion radicals $\left(\mathrm{O}_{2}\right)$ under in vivo conditions (Skibba et al., 1988). Xanthine oxidase activity on ADX showed a significant elevation in heart and muscle tissues as well. The elevated xanthine oxidase activity observed in the present study in turn might be responsible for the increased generation of superoxide radicals in these tissues. Therefore, the presence of increased free radicals could have induced production of SOD enzyme in these tissues, resulting in the elevation of SOD activity. The relatively high sensitivity of the myocardium towards ROS can be explained due to low level of antioxidant enzyme activity. The enhanced SOD activity may be due to compensatory mechanism to cope with excess $\mathrm{O}_{2}$ radicals.

Catalase activity was significantly decreased in liver and muscle of ADX rats over SO. Evidences suggest that $\mathrm{O}_{2}$ itself affect directly the CAT activity (Kono and Fridovich, 1982). It has also been reported that CAT is inactivated by hydroxyl radical (Piegeolet and Corbisier, 1990). It was observed that increased production of reactive oxygen metabolites results in an increase in the level of antioxidants. Further more, iron is an essential co-factor for the activity of catalase enzyme. An Iron deficiency

Table 1. Alterations in the levels of glucose-6-phosphate dehydrogenase, superoxide dismutase, catalase and xanthine oxidase in Liver and Heart of both adrenalectomized and sham operated rats (Values are mean, \pm S.D of six individual observations. $\$+$ or indicate the percent increase or decrease over sham operated control respectively. "p" denotes the level of statistical significance. "NS" indicates non-significant change).

\begin{tabular}{|c|c|c|c|c|c|c|c|}
\hline \multirow[b]{2}{*}{$\begin{array}{l}\text { S. } \\
\text { No. }\end{array}$} & \multirow[b]{2}{*}{ Parameter } & \multicolumn{3}{|c|}{ Liver } & \multicolumn{3}{|c|}{ Heart } \\
\hline & & $\begin{array}{c}\text { Sham } \\
\text { operated }\end{array}$ & $\begin{array}{l}\text { A drena- } \\
\text { lectomized }\end{array}$ & $\begin{array}{l}\text { Percent } \$ \\
\text { change }\end{array}$ & $\begin{array}{c}\text { Sham } \\
\text { oper ated }\end{array}$ & $\begin{array}{l}\text { A dr ena- } \\
\text { lectomized }\end{array}$ & $\begin{array}{l}\text { Percent } \$ \\
\text { change }\end{array}$ \\
\hline 1 & $\begin{array}{l}\text { G-6-PDH } \\
\text { moles } / \mathrm{mg} \\
\text { protein } / \mathrm{hr}\end{array}$ & $\begin{array}{c}0.020 \\
\pm 0.001\end{array}$ & $\begin{array}{c}0.028 \\
\pm 0.001\end{array}$ & $\begin{array}{c}+40 \\
t=-9.84 \\
p=0.004\end{array}$ & $\begin{array}{c}0.014 \\
\pm 0.001\end{array}$ & $\begin{array}{c}0.019 \\
\pm 0.001\end{array}$ & $\begin{array}{c}+35.71 \\
t=-7.27 \\
p=0.001\end{array}$ \\
\hline 2 & $\begin{array}{l}\text { SOD } \\
\text { units / mg } \\
\text { protein / min }\end{array}$ & $\begin{array}{c}9.14 \\
\pm 0.56\end{array}$ & $\begin{array}{c}9.33 \\
\pm 0.46\end{array}$ & $\begin{array}{c}+2.07 \\
\mathrm{t}=-0.641 \\
\mathrm{NS}\end{array}$ & $\begin{array}{l}12.40 \\
\pm 1.04\end{array}$ & $\begin{array}{r}20.89 \\
\pm 2.07\end{array}$ & $\begin{array}{l}+68.46 \\
t=-8.98 \\
p=0.001\end{array}$ \\
\hline 3 & $\begin{array}{l}\text { Catalase } \\
\text { moles /mg } \\
\text { protein / min }\end{array}$ & $\begin{array}{c}0.077 \\
\pm 0.005\end{array}$ & $\begin{array}{c}0.054 \\
\pm 0.004\end{array}$ & $\begin{array}{c}-29.87 \\
t=8.13 \\
p=0.001\end{array}$ & $\begin{array}{c}0.271 \\
\pm 0.018\end{array}$ & $\begin{array}{c}0.286 \\
\pm 0.019\end{array}$ & $\begin{array}{c}+5.53 \\
\mathrm{t}=-1.44 \\
\quad \mathrm{NS}\end{array}$ \\
\hline 4 & $\begin{array}{l}\text { Xanthine oxidase } \\
\text { moles /mg } \\
\text { protein / hr }\end{array}$ & $\begin{array}{c}0.175 \\
\pm 0.003\end{array}$ & $\begin{array}{c}0.160 \\
\pm 0.005\end{array}$ & $\begin{array}{c}-8.57 \\
\mathrm{t}=6.05 \\
\mathrm{p}=0.001\end{array}$ & $\begin{array}{c}0.042 \\
\pm 0.003\end{array}$ & $\begin{array}{c}0.048 \\
\pm 0.004\end{array}$ & $\begin{array}{c}+14.28 \\
\mathrm{t}=-3.0 \\
\mathrm{p}=0.013\end{array}$ \\
\hline
\end{tabular}


Table 2. Alterations in the levels of glucose-6-phosphate dehydrogenase, superoxide dismutase, catalase and xanthine oxidase in kidney and muscle of both adrenalectomized and sham operated rats (Values are mean, \pm S.D of six individual observations. $\$+$ or - indicate the percent increase or decrease over sham operated control respectively. "p" denotes the level of statistical significance. "NS" indicates non-significant change).

\begin{tabular}{|c|c|c|c|c|c|c|c|}
\hline \multirow[t]{2}{*}{ S.No. } & \multirow[b]{2}{*}{ Parameter } & \multicolumn{3}{|c|}{ Kidney } & \multicolumn{3}{|c|}{ M uscle } \\
\hline & & $\begin{array}{c}\text { Sham } \\
\text { operated }\end{array}$ & $\begin{array}{c}\text { Adrena- } \\
\text { lectomized }\end{array}$ & $\begin{array}{l}\text { Percent } \$ \\
\text { change }\end{array}$ & $\begin{array}{c}\text { Sham } \\
\text { operated }\end{array}$ & $\begin{array}{c}\text { Adrena- } \\
\text { lectomized }\end{array}$ & $\begin{array}{l}\text { Percent } \$ \\
\text { change }\end{array}$ \\
\hline 1 & $\begin{array}{l}\text { G-6-PDH } \\
\text { moles /mg } \\
\text { protein / hr }\end{array}$ & $\begin{array}{c}0.035 \\
\pm 0.002\end{array}$ & $\begin{array}{c}0.019 \\
\pm 0.001\end{array}$ & $\begin{array}{c}-45.71 \\
t=16.49 \\
p=0.001\end{array}$ & $\begin{array}{c}0.036 \\
\pm 0.002\end{array}$ & $\begin{array}{c}0.032 \\
\pm 0.003\end{array}$ & $\begin{array}{c}-11.11 \\
\mathrm{t}=2.19 \\
\mathrm{NS}\end{array}$ \\
\hline 2 & $\begin{array}{l}\text { SOD } \\
\text { units / mg protein/ } \\
\text { min }\end{array}$ & $\begin{array}{l}11.99 \\
\pm 1.06\end{array}$ & $\begin{array}{r}10.95 \\
\pm 1.03\end{array}$ & $\begin{array}{l}-8.67 \\
t=1.72 \\
N S\end{array}$ & $\begin{array}{r}12.74 \\
\pm 1.18\end{array}$ & $\begin{array}{l}22.10 \\
\pm 2.10\end{array}$ & $\begin{array}{l}+73.46 \\
t=-8.69 \\
p=0.001\end{array}$ \\
\hline 3 & $\begin{array}{l}\text { Catalase } \\
\text { moles } / \mathrm{mg} \\
\text { protein } / \mathrm{min}\end{array}$ & $\begin{array}{c}0.046 \\
\pm 0.003\end{array}$ & $\begin{array}{c}0.065 \\
\pm 0.005\end{array}$ & $\begin{array}{l}+41.30 \\
t=-7.43 \\
p=0.001\end{array}$ & $\begin{array}{c}0.441 \\
\pm 0.025\end{array}$ & $\begin{array}{c}0.275 \\
\pm 0.019\end{array}$ & $\begin{array}{c}-37.64 \\
t=11.78 \\
p=0.001\end{array}$ \\
\hline 4 & $\begin{array}{l}\text { Xanthine oxidase } \\
\text { moles /mg } \\
\text { protein / hr }\end{array}$ & $\begin{array}{c}0.061 \\
\pm 0.004\end{array}$ & $\begin{array}{c}0.073 \\
\pm 0.006\end{array}$ & $\begin{array}{l}+19.67 \\
t=-4.05 \\
p=0.002\end{array}$ & $\begin{array}{c}0.068 \\
\pm 0.005\end{array}$ & $\begin{array}{c}0.121 \\
\pm 0.011\end{array}$ & $\begin{array}{l}+77.94 \\
t=-9.46 \\
p=0.001\end{array}$ \\
\hline
\end{tabular}

would not only impair oxygen transport in the body, but also compromise the body's antioxidant capacity by lowering catalase activity in the cell (Halliwell and Gutteridge 1989; Powers et al ., 2004).

In contrast to liver and muscle a significant increase in the catalase activity was observed in kidney on ADX. The organisms exposed to oxidative stress are known to undergo adaptational changes in antioxidant defense systems (Somani et al., 1995). Increased catalase activity in the present study suggests its active involvement in decomposition of hydrogen peroxide during ADX. Increased catalase activity is in consonance with increased SOD activity under stress. The catalase activity has been reported to be increased in liver, heart, skeletal muscle, brain and plasma of rat subjected to exercise training (Husain, 2002; Husain and Hazelrigg, 2002; Husain, 2003).

Heart tissue showed an elevation in xanthine oxidase activity in ADX rats than SO. The elevated enzyme activity also indicates the nitrogen balance of the tissue where XOD is produced when the native form of XDH is altered by sulfhydral oxidation or by limited proteolysis (Dellacorte and Stnipe, 1972).

A significant increase in the xanthine oxidase activity was observed in kidney of adrenalectomized rats than Sham operated. Conversion of xanthine dehydrogenase to xanthine oxidase under adrenalectomy may be one of the reasons for elevated XOD activity.

In the present work the increased activity of XOD with reference to ADX was observed in muscle. The elevated levels of XOD might result in generation of free radicals of $\mathrm{O}_{2}$ and $\mathrm{OH}$ species and there by resulting in increased uric acid production. During the time of stress caused by adrenalectomy the tissues suffering temporary ATP imbalance leading to the failure of ion Pump's operation and thus increase the intracellular calcium. Protiens becomes activated with the result of increased calcium levels which in turn converts xanthine dehydrogenases to xanthine oxidase. This is supported by enhanced uptake of oxygen leading to the increased oxidative metabolism which in turn increases the production of free radicals and uric acid.

The induction of xanthine oxidase coupled with lipid peroxidation indicates not only the generation of free radicals but also disposal of ammonia as less toxic uric acid which contributes to the aetiology of adrenalectomy.

\section{REFERENCES}

Asha Devi, S., Prathima, S. and Subramanyam, M.V. (2003). Dietary vitamin E and physical exercise: II. Antioxidant status and lipofuscin-like substances in aging rat heart. Exp Gerontol., 38 (3) : 291-297.

Bhaskar M., Stith R.D., Brackett D.J., Wilson M.F., Learner M.R and Reddy Y.S. (1989). Changes in myocardial ATPases in chronically adrenalectomized rats with and without glucocorticoid replacement. Biochem. Med. M etabol. Bio., 42: $118-124$.

Dellacorte, E. and Stnipe, F. (1972). The regulation of liver xanthine oxidase involvement of the thiol groups in the conversion of the enzyme activity from dehydrogenase into oxidase (type 0) and purification of the enzyme. Biochem J., 126: 739-745.

Halliwell,B. and Gutteridge, J.M.C. (1989). F ree Radicals in Biology and Medicine. $2^{\text {nd }}$ edition UK, Oxford, Clarendon.

Helmutsies. (1985) In : oxidative stress (Helmut Sies ED) Academic press, New York, pp.22-25.

Hussain, K. (2002). Exercise conditioning attenuates the hypertensive effects of nitric oxide synthase inhibitor in rat. M ol. Cell. Biochem., 231 (1-2) : 129-137.

Husain, K. (2003). Interaction of exercise training and chronic NOS inhibition on blood pressure, heart rate, NO and 
antioxidants in plasma of rats. Pathophysiology, 10 (1):4756.

Husain, K. and Hazelrigg, S.R. (2002). Oxidative injury due to chronic nitric oxide synthase inhibition in rat: effect of regular exercise on the heart. Biochem. Biophys. Acta., 1587(1): 7582.

Jacob, R.A. and Burri, B.J. (1996). Oxidative damage and defense. Am. J. Clin. Nutr., 63 (6) : 985S-990S.

Kaul, L. and Berdanier, C.D. (1975). Effect of pancreatectomy or adrenalectomy on the responses of rats to meal-feeding. J. Nutr., 105 (9) : 1176-85.

Kono, Y. and Fridovich, I. (1982). Superoxide radical inhibits catalase. J. B oil. C hem., 257: 5751.

Nelson, D.H. and Ruhmann-Wennhold, A. (1975). Corticosteroids increase superoxide anion production by rat liver microsomes. J. Clin. Invest., 56 (4): 1062-5.

Parfenova, N.S. and Shanygina, K.I.(1976). Nature of changes in the activity of certain enzymes of energy metabolism in the liver after partial sympathectomy. Vopr. M ed. K him., 22 (6) : $08-12$
Piegeolet, E. and Corbisier, P. (1990). Glutathione peroxidase and superoxide dismutase and catalase inactivation by $\mathrm{AO}$. M ech. Age. D ev.,51: 283.

Powers, S.K., DeRuisseau, K.C., Quindary, J. and Hamilton, K.L. (2004). Dietary antioxidants and exercise. J . Sports Sci., 22: 81-94.

Schroder, H., Navarro, E., Mora, J., Galiano. D. and Tramullas. A. (2001). Effects of $\alpha$-tocopherol, $\beta$-carotene and ascorbic acid on oxidative, hormonal and enzymatic exercise stress markers in habitual training activity of professional basket ball players. Eur. J. Nutr., 40 (4) : 178-84.

Skibba,J., Power, R., Stamdnicka, A. and Kalinfleisch, J. (1988). Lipid peroxidation after hyperthermic perfusion of rat liver. FASEB J. 12(A376) Medical college Wison, Milwankee, W.S. 3226 and Zablock: Veterans administration, Milwankee, W. $153 / 98$.

Somani, S.M. and Arroyo, C.M. (1995). Exercised training generates ascorbate free radicals in rat heart. Indian J. Physiol. Pharmacol., 39 (4) : 323-329. 